\title{
APLIKASI METODE DISKUSI DAN TUGAS DALAM MENINGKATKAN HASIL BELAJAR SISWA SMPN 2 PEKALONGAN TAHUN PELAJARAN 2011/2012
}

\author{
Endri Sugiyanto \\ Pendidikan biologi FKIP Universitas Muhammadiyah Metro \\ E-mail: sugiyantoendri@yahoo.co.id
}

\begin{abstract}
The aim of the research was to increasing of science learning echievement. The research was to implemented by the Classroom Action Research (CAR) in SMPN 2 Pekalongan class VIII ${ }_{1}$ academic year 2011/2012. The result of this research was the application of the discussion and assignment method, students learning achievement increase from the cycle I to cycle II by 16,12\%. Based on the research the researcher suggest that the scence teachers need to apply the discussion and assignment method to increase achievement of science.
\end{abstract}

Kata kunci : Metode Diskusi dan Tugas, Hasil Belajar Siswa

Belajar merupakan suatu proses usaha yang dilakukan seseorang untuk memperoleh suatu perubahan tingkah laku serta pengetahuan yang baik secara keseluruhan sebagai hasil pengalamannya sendiri dalam interaksi dengan lingkungan. Sedangkan prestasi belajar merupakan taraf keberhasilan murid atau penguasaan materi dalam mempelajari materi pelajaran di sekolah dan dinyatakan dalam bentuk skor atau nilai yang diperoleh dari hasil tes dalam materi pelajaran tertentu. Prestasi yang baik akan sulit dicapai bila guru tidak memiliki kompetensi dalam pembelajaran. Sebagai tolak ukur keberhasilan dari sebuah pembelajaran, biasa dilihat dari ketuntasan hasil belajar siswa pada setiap pokok bahasan dengan diberikannya soal evaluasi sebagai bahan pengukur kemampuan siswa terhadap penguasaan materi yang telah diserap selama pembelajaran berlangsung.

Dalam pelaksanaannya guru memancing partisipasi siswa, seperti ketika guru memberikan pertanyaan, guru langsung memberikan kesempatan pada siswa untuk berpikir dan guru mengharapkan siswa memberikan jawaban yang ditanyakan dari guru tersebut. Pembelajaran seperti ini seharusnya menjadikan siswa lebih aktif dan siswa cenderung berpikir kritis serta menggunakan logika sebagai dasar berpikir dalam memecahkan dari setiap permasalahan. dengan memberikan kesempatan yang telah dilakukan tetap terjadi permasalahan yang dihadapi guru dalam pembelajaran yang dilakukan dalam kelas yakni kurangnya partisipasi siswa dalam pembelajaran yang dilakukan selama pembelajaran tersebut berlangsung. Selain itu dengan kurangnya partisipasi siswa dalam pembelajaran akan memberikan dampak yang signifikan terhadap hail yang dicapai dalam hasil belajar siswa. Dalam tabel 1 dapat dilihat hasil belajar siswa pada pra_PTK. 
Tabel 1. Data Hasil Belajar Siswa pada Pra_PTK

\begin{tabular}{|c|c|c|c|}
\hline Nilai & Kriteria & Jumlah Siswa & Persentase \\
\hline$\geq 68$ & Tuntas & 19 & $51,35 \%$ \\
\hline$<68$ & Tidak Tuntas & 18 & $48,64 \%$ \\
\hline \multicolumn{2}{|c|}{ Jumlah } & 37 & $100 \%$ \\
\hline
\end{tabular}

Data hasil prasurvai nilai hasil belajar IPA terpadu siswa kelas $\mathrm{VIII}_{1}$ dan Kriteria Ketuntasan Minimal (KKM) IPA terpadu yang ditetapkan di SMP Negeri 2 Pekalongan yaitu 68, ada sebanyak 18 siswa atau 48,37\% dari 37 siswa yang tidak dapat mencapainya, sedangkan target yang diinginkan oleh sekolah untuk mata pelajaran IPA terpadu, siswa yang tuntas mencapai 75\%. SMP Negeri 2 Pekalongan memberikan target ketuntasan belajar siswa sebesar 75 \% karena keberhasilan suatu pembelajaran yang optimal dimana siswa mampu menyerap atau memahami suatu ilmu pengetahuan dengan kriteria 75\% telah mampu menguasai. Maka ketuntasan belajar siswa tersebut belum mencapai standar yang diharapkan. Berkaitan dengan permasalahan yang terjadi, maka perlu diadakan proses pembelajaran yang menekankan titik aktivitas belajar siswa yang lebih mendalam dengan penguatan serta motivasi dari lingkungan supaya menciptakan suasana belajar dan akan memberikan dampak positif pada hasil belajar siswa dengan mengalami peningkatan pada hasil belajarnya.

Menurut Syah (2011:216) "prestasi belajar ideal meliputi segenap ranah psikologis yang berubah sebagai akibat pengalaman dan proses belajar siswa”. Hal ini bermaksud prestasi belajar akan didapatkan bila siswa tersebut melakukan kegiatan yang dikatakan belajar. Sedangkan menurut Yasa (2008) prestasi belajar dapat diartikan "sebagai hasil yang dicapai oleh individu setelah mengalami suatu proses belajar dalam jangka waktu tertentu”. Selain itu juga prestasi selalu dihubungkan dengan aktivitas tertentu, seperti dikemukakan oleh Gagne yang dikutip Abdullah (2008) "dalam setiap proses akan selalu terdapat hasil nyata yang dapat diukur dan dinyatakan sebagai hasil belajar (Achievement) seseorang”.

Sehingga dapat diberikan kesimpulan hasil belajar merupakan sebuah pencapaian akan penguasaan materi yang telah dipelajari dan dilakukan pembelajarannya baik dalam ruang kelas atau di luar kelas, atau dengan kata lain hasil belajar dapat dilihat melalui hasil evaluasi dari setiap pokok bahasan sebagai alat ukur dari keberhasilan pembelajaran yang telah dilakukan.

Untuk mencapai proses pembelajaran dan hasil belajar dipengaruhi beberapa faktor diantaranya penggunaan metode. Diskusi merupakan komunikasi seseorang berbicara satu dengan yang lain, saling berbagi gagasan dan pendapat. Menurut Mulyasa (2009:116) "diskusi dapat diartikan sebagai percakapan responsif yang dijalin oleh pertanyaan-pertanyaan problematis yang diarahkan untuk memperoleh pemecahan masalah”. Hal ini selaras dengan pendapat Djamarah dan Zain (2010:87) metode diskusi adalah "cara penyajian pelajaran dimana siswa-siswa dihadapkan pada suatu masalah yang bisa berupa pernyataan atau pertanyaan yang bersifat problematis untuk dibahas dan dipecahkan bersama”. Jadi dalam pembelajaran yang dilakukan dengan metode diskusi akan membuat siswa terbiasa menghadapi dan memecahkan suatu permasalahan. selain itu, diskusi bukan debat yang bersifat mengadu 
argumentasi, namun diskusi lebih bersifat bertukar pengalaman antara sesama teman, dengan guru dan akhirnya bertukar pengalaman bersama-sama, karena belajar bukan saja milik siswa namun juga milik bersama.

Menurut Sofa (2008) bahwa metode diskusi dalam pembelajaran adalah: 1) Siswa belajar bermusyawarah, 2) Siswa mendapat kesempatan untuk menguji tingkat pengetahuan masingmasing, 3) Belajar menghargai pendapat orang lain, dan 4) Mengembangkan cara berpikir dan sikap ilmiah. Selain itu juga menurut Suryobroto (dalam Trianto, 2010:123) bahwa diskusi dapat digunakan oleh guru dengan pertimbangan : 1) Memanfaatkan berbagai kemampuan yang ada (dimiliki) oleh siswa, 2) Memberikan kesempatan kepada para siswa untuk menyalurkan kemampuannya masingmasing, 3) Memperoleh umpan balik dari siswa tentang apakah tujuan yang telah dirumuskan telah tercapai, 4) Membantu para siswa belajar berpikir teoritis dan praktis lewat berbagai mata pelajaran dan kegiatan sekolah, 5) Membantu para siswa belajar menilai kemampuan dan peranan diri sendiri maupun teman-temannya (orang lain), 6) Membantu para siswa menyadari dan mampu merumuskan berbagai masalah yang dilihat baik dari pengalaman sendiri maupun dari pelajaran sekolah, 7) Mengembangkan motivasi untuk belajar lebih lanjut. Berdasarkan dari pengalaman belajar siswa juga akan memberikan sebuah penguatan dan motivasi diri dalam diri siswa untuk mencapai tujuan dalam belajar.

Menurut Gibbs (dalam Mulyasa, 2009:164) kreativitas dapat dikembangkan dengan memberi kepercayaan, komunikasi yang bebas, pengarahan diri, dan pengawasan yang tidak terlalu ketat. Dengan pemberian perlakuan tersebut aktivitas siswa akan memberikan pengaruh terhadap peningkatan cara belajar serta aktivitas yang dilakukan. Peningkatan aktivitas ini terjadi karena dalam setiap akhir pembelajaran yang telah dilakukan guru memberikan sedikit motivasi dalam menutup pembelajaran, serta menguatkan rasa ingin belajar yang telah ada dalam diri siswa. Serta penguatan siswa dala pembelajaran akan memberikan kebebasan siswa dalam berekspresi dengan gaya belajar dan memecahkan permasalahan yang dihadapinya.

Menurut Djajadisastra (dalam Trinasari, 2011:9) metode tugas merupakan "suatu cara mengajar yang dapat dirincikan oleh adanya perencanaan antara murid dan guru mengenai suatu persoalan yang harus diselesaikan oleh siswa”. Melalui pemberian tugas berarti seorang guru memberikan kesepakatan pada siswa untuk memecahkan masalah sehingga siswa aktif. Dalam pembelajaran harus ditekankan pada proses pembelajaran harus melibatkan siswa dalam mengelola dan memahami materi yang disampaikan guru. Hal ini senada dengan pendapat Silberman (2004:20) yang mengatakan bahwa untuk mengingat apa yang telah diajarkan, siswa harus mengelolanya atau memahaminya. Seorang guru tidak dapat dengan serta-merta menuangkan sesuatu ke dalam benak para siswanya, karena mereka sendirilah yang harus menata apa yang meraka dengar dan lihat menjadi satu kesatuan yang bermakna. Tanpa peluang mendiskusikan, mengajukan pertanyaan, mempraktikkan, dan barangkali bahkan mengajarkannya kepada siswa lain, proses belajar yang sesungguhnya tidak akan terjadi

Berdasarkan beberapa hal di atas, maka melalui aplikasi metode diskusi dan tugas akan memberikan peningkatan dari hasil belajar siswa. Hal ini iakibatkan dalam diskusi siswa diberikan peran melakukan penggalian informasi yang selengkap mungkin dalam menghadapi permasalahan yang diberikan sebagai memahami kemampuan dan mengembangkan ranah kognitif siswa, selain itu dengan tugas 
yang dilakukan siswa akan memberikan lebih banyak sumber dan literatur siswa dalam menyelesaikan permasalahan yang diberikan. Selain itu juga dengan menyelesaikan tugas siswa akan dibiasakan menyelesaikan tanggung jawab yang menjadikan pola pikir dan kemandirian siswa terlatih sebagai bekal dalam bersosialisasi dengan lingkungan di luar sekolah. Dengan membiasakan siswa melakukan berdiskusi dan mengerjakan tugas maka akan memberikan sustu pemahaman dalam belajar kita tidak secara individual sehingga dengan belajar bersama dalam memecahkan permasalahan bersamasama siswa akan belajar yang lebih bermakna dan memberikan pengetahuan dan pemahaman yang lebih mendalam dari sebuah materi.

Berdasarkan latar belakang di atas, dapat dirumuskan masalah dalam penelitian ini yaitu : Apakah pembelajaran dengan aplikasi metode diskusi dan tugas dapat meningkatkan hasil belajar IPA terpadu siswa kelas $\mathrm{VIII}_{1}$ semester ganjil SMP Negeri 2 Pekalongan tahun pelajaran 2011/2012?. Penelitian ini bertujuan untuk meningkatkan hasil belajar IPA terpadu siswa kelas $\mathrm{VIII}_{1}$ SMP Negeri 2 Pekalongan semester ganjil Tahun Pelajaran 2011/2012. Sedangkan manfaat yang diharapkan dari penelitian ini yaitu : 1) Memberikan masukan bagi guru dan calon guru IPA dalam upaya untuk meningkatkan aktivitas, dan hasil belajar IPA terpadu; 2) Menjadikan pembelajaran yang menyenangkan bagi siswa, serta meningkatkan aktivitas belajar, dan hasil belajar IPA terpadu; 3) Hasil penelitian ini memberikan sumbangan yang bermanfaat bagi sekolah dalam mendukung perbaikan pembelajaran IPA terpadu khususnya.

\section{METODE}

Penelitian ini merupakan
penelitian tindakan kelas yang dilaksanakan pada semester ganjil tahun pelajaran 2011/2012 pada siswa SMP Negeri 2 Pekalongan pada standar kompetensi memahami kegunaan bahan kimia dalam kehidupan, dengan kompetensi dasar : 1) Mendeskripsikan bahan kimia alami dan bahan kimia buatan dalam kemasan yang terdapat dalam bahan makanan, dan 2) Mendeskripsikan sifat atau pengaruh zat adiktif dan psikotropika. Penelitian tindakan kelas ini dilaksanakan dalam 2 siklus yang meliputi tahap-tahap dalam penelitian yaitu : 1) perencanaan, 2) pelaksanaan tindakan, 3) observasi dan evaluasi tindakan, dan 4) refleksi dari perjalanan setiap pertemuan yang dilaksanakan selama pembelajaran. Pembelajaran dilaksanakan selama 3 kali pertemuan dengan alokasi waktu setiap pertemuan (2 x 40 menit) sedangkan penelitian dilaksanakan mulai tanggal 22 November sampai dengan 3 Desember 2011. Penelitian dilaksanakan di SMP Negeri 2 Pekalongan Lampung-timur pada semester ganjil tahun pelajaran 2011/2012 dengan subjek penelitian siswa VIII $_{1}$ dengan jumlah siswa 37 siswa dengan tingkat kemampuan yang beragam. Sedangkan objek penelitian metode diskusi dan tugas dalam meningkatkan hasil belajar siswa.

Dalam penelitian, peneliti melakukan tahap tahap penelitian dengan memngkaji materi yang akan dilakukan pembelajarannya selama penelitian, setelah itu mempersiapkan segala perangkat pembelajaran yang akan digunakan selama penelitian seperti silabus, rencana pelaksanaan pembelajaran serta soal sebagai evaluasi pembelajaran.dalam tahap pelaksanaan peneliti melaksanaan pembelajaran dengan aplikasi metode diskusi dan tugas dan mengamati aktivitas yang dilakukan siswa sebagai bahan kajian 
apakah siswa yang melakukan aktivitas belajar yang baik akan memberikan hasil belajar yang baik. Pada setiap akhir siklus diadakan tes evaluasi yang digunakan sebagai tolak ukur akan kemampuan dipahaminya materi oleh siswa dan diberikan. Pada tahap terakhir adalah refleksi dilakukan pada setiap akhir pertemuan dan akhir siklus dalam menkaji pembelajaran yang dilakukan.

\section{HASIL}

Berdasarkan hasil evaluasi dengan tes sebahai tolak ukur pemahaman siswa terhadap pembelajaran yang telah dilakukan. Hasil belajar siswa pada praPTK siswa yang mengalami ketuntasan sebesar 51,35\% sedangkan siswa yang belum tuntas sebesar $48,64 \%$. Untuk penelitian siklus I siswa yang tuntas sebesar $62,12 \%$ dan siswa yang belum tuntas sebesar $37,88 \%$, sedangkan pada siklus II siswa yang mengalami ketuntasan sebesar 78,37\% dan yang belum tuntas sebesar 21,33\%. Untuk melihat peningkatan hasil belajar siswa secara signifikan data dapat di lihat pada Gambar 1.

\section{PEMBAHASAN}

Pembelajaran dengan aplikasi metode diskusi dan tugas memberikan pembelajaran yang menyenangkan sebanding peningkatan hasil belajar yang diperoleh siswa pada setiap akhir siklus yang diberikan soal evaluasi. Hal tersebut dibuktikan dengan peningkatan hasil belajar siswa pada siklus I dan peningkatan pula peda siklus II. Dari hasil evaluasi siklus I siswa yang mengelami ketuntasan hasil belajar siswa $62,16 \%$ dan belum mencapai target yang ditentukan oleh sekolah, dan pada siklus II hasil belajar siswa yang mengelami ketuntasan mencapai 78,37\% target yang ditentukan oleh sekolah telah tercapai dengan ketuntasan belajar siswa lebih dari $75 \%$ siswa yang mengalami ketuntasan belajar. Menurut Djamarah dan Zain (2010:105) "keberhasilan belajar mengajar tercapai apabila suatu belajar dinyatakan berhasil apabila mencapai tujuan dari perencanaan/ target”. Sesuai dengan pendapat tersebut ketercapaian ketuntasan hasil belajar yang ditentukan oleh sekolah mengindikasikan pembelajaran yang dilaksanakan dengan aplikasi metode diskusi dan tugas memberikan dampak pembelajaran yang menyenangkan dan bermakna sehingga pemehaman siswa terhadap materi dikuasai dengan baik. Selain itu terdapat faktor motivasi yang dapat berpengaruh terhadap keberhasilan dari hasil belajar siswa dan faktor tersebut dapat berasal dari dalam diri siswa yakni rasa keingintahuan yang besar dalam proses pembelajaran.

Dalam hal motivasi menurut Gleitman dan Reber (dalam Syah, 2011:153) "motivasi merupakan pemasok daya (Energizer) untuk bertingkah laku terarah”. Motivasi itu dapat berasal dari dalam diri siswa (intrinsik) dan keadaan yang mendorong namun berasal dari luar individu (ekstrinsik). Motivasi yang diberikan oleh guru dalam pembelajaran akan meningkatkan rasa ingin belajar siswa dan meningkatkan aktivitas belajar siswa serta frekuensi belajar atau frekuensi aktivitas belajar siswa. Dengan penguatan motivasi ekstrinsik peneliti bisa meningkatkan target dari ketercapaian seberapa besar hasil yang diinginkan oleh siswa terhadap hasil belajar yang akan didapatkan. 


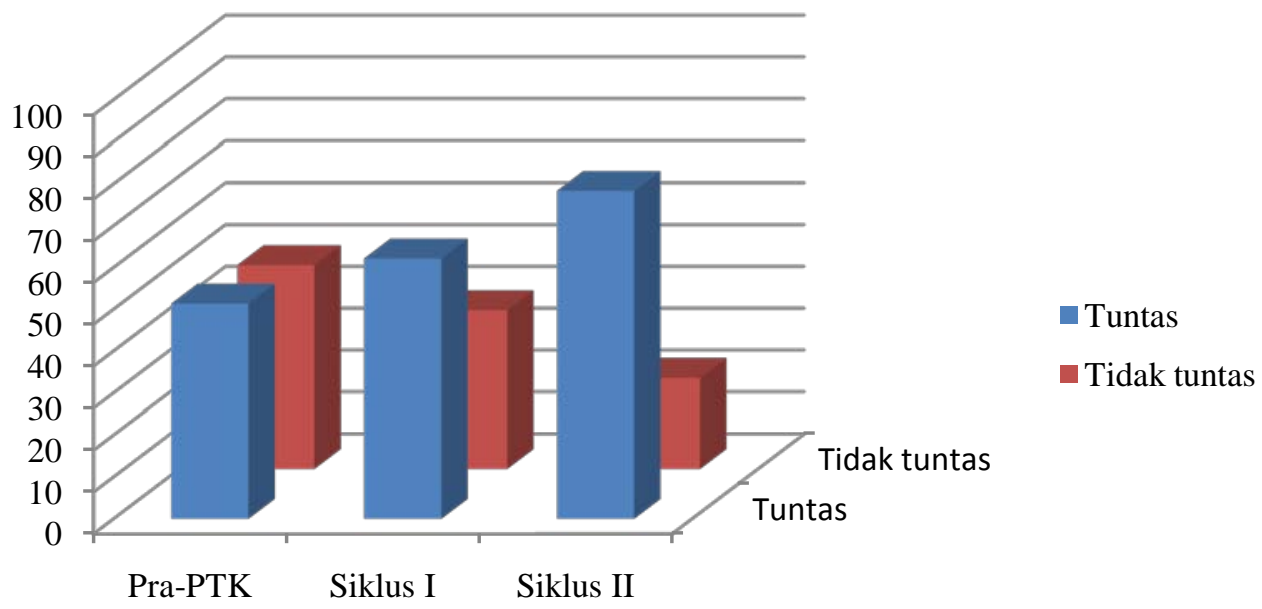

Gambar 1. Peningkatan Hasil Belajar Siswa

Dengan penguatan motivasi yang berfungsi sebagai dorongan kepada siswa, maka siswa akan termotivasi dengan berbagai hal-hal yang mampu membuat siswa belajar dengan maksimal mungkin dengan mencapai nilai tertinggi yang diharapkannya.

Dalam pembelajaran banyak sekali hal yang mampu mempengaruhi hasil belajar siswa, sehingga dalam penelelitian ini pengkondisian dalamkemampuan penciptaan suasana yang baik dalam belajar harus guru atau peneliti kuasai sehingga selama pembelajaran tidak banyak hal yang mempengaruhi siswa dan belajar siswa akan mengalami peningkatan bahkan meningkatkan hasil belajar siswa.

\section{KESIMPULAN DAN SARAN}

\section{Kesimpulan}

Berdasarkan hasil penelitian yang dilakukan, dapat disimpulkan bahwa aplikasi metode diskusi dan tugas meningkatkan hasil belajar siswa kelas VIII1 SMP Negeri 2 Pekalongan Tahun Pelajaran 2011/2012.

\section{Saran}

Berdasarkan kesimpulan dari hasil penelitian ini, peneliti memberikan saran sebaiknya guru mengaplikasikan metode diskusi dan tugas untuk meningkatkan hasil belajar siswa dan metode ini dapat menjadi alternatif metode pembelajaran yang digunakan dalam pembelajaran IPA terpadu.

\section{DAFTAR RUJUKAN}

Abdullah, Abu Muhammad Ibnu. 2008. "Prestasi Belajar". (Online). (http://SpesialisTorch.Com/Content/View/120/29/). diakses 5 Mei 2011.

Djamarah, Syaiful Bahri dan Zain, Aswan. 2010. Strategi Belajar Mengajar. Jakarta : Rineka Cipta.

Mulyasa, E. 2009. Menjadi Guru Profesional. Bandung: PT. Remaja Rosdakarya.

Syah, Muhibbin. 2011. Psikologi Belajar. Jakarta: Rajawali Press.

Silberman, Melvin L. 2004. Active Learning 101 Cara Belajar Siswa 
Aktif. Bandung: Nuansa dan Nusa Media.

Sofa. 2008. "Metode Diskusi dalam Pembelajaran”. (Online). (http://massofa.wordpress.com/200 8/07/13/metode-diskusi-dalampembelajaran/). diakses 25 Oktober 2011.

Trianto. 2010. Mendesain Model Pembelajaran Inovatif-Progresif. Jakarta: Kencana.

Trinasari. 2011. Penerapan Metode Pemberian Tugas Melalui Identifikasi Tumbuhan Dengan Kunci Determinasi Untuk Meningkatkan Aktivitas dan Hasil Belajar Biologi Siswa Kelas $X$ Semester Genap SMA UTAMA WACANA Metro Tahun Pelajaran 2010/2011. Skripsi tidak diterbitkan. Metro: Fakultas Keguruan dan Ilmu Pendidikan Universitas Muhammadiyah Metro.

Yasa, Doantara. 2008. "Aktivitas dan Prestasi Belajar”. (Online). (http://ipotes.wordpress.com/2008/ 05/24/prestasi-belajar/). diakses 5 mei 2011. 